\title{
PENGARUH RASIO KEUANGAN DAERAH TERHADAP PERTUMBUHAN EKONOMI KABUPATEN/KOTA DI PROVINSI ACEH
}

\author{
Muhammad Azhari ${ }^{1}$, Andria Zulfa ${ }^{2 *}$, Murtala ${ }^{3}$ \\ ${ }^{123}$ Program Pascasarjana Ilmu Manajemen, Universitas Malikussaleh Lhokseumawe \\ Email : azhari@gmail.com ${ }^{1}, \underline{\text { andriazulfa@unimal.ac.id }}^{2}$, murtala@unimal.ac.id ${ }^{3}$
}

\begin{abstract}
This study aims to examine the effect of regional independence ratio, regional effectiveness ratio, regional efficiency ratio and regional income growth ratio on economic growth. The research data used is a combination of cross sections with time series in 23 districts / cities in Aceh Province during 2014-2018, which is obtained from the Budget Realization Report (LRA) issued by the Directorate General of Regional Financial Balance, Ministry of Finance (DJPK Kemenkeu). The data analysis method used is Panel Data Regression with Eviews 9 assistance.The results of this study prove that regional independence ratio, regional effectiveness ratio and regional efficiency ratio have a positive and significant effect on economic growth, while regional income growth ratio has no significant effect on economic growth in Regencies / Cities in Aceh Province
\end{abstract}

Keywords: Regional Independence Ratio, regional effectiveness ratio, regional efficiency ratio , regional income growth ratio and economics growth

\section{PENDAHULUAN}

Pertumbuhan ekonomi daerah menjadi aspek yang penting dalam menunjang pertumbuhan ekonomi nasional (Azwar et al., 2013). Hal ini dikarenakan pemerataan perekonomian memiliki dampak jangka panjang dalam pembangunan nasional dan pendapatan masyarakat (Resosudarmo et al., 2011). Pertumbuhan ekonomi juga menjadi indikator tingkat kesejahteraan masyarakat daerah, tingkat penguasaan dan perkembangan teknologi di suatu daerah, serta menjadi indikator keberhasilan pembangunan suatu daerah (Peterseon, 2017; Mundlak, 2001; Harahap et al., 2012). Tingkat pertumbuhan ekonomi juga tidak terlepas dari keberhasilan pemerintah dalam meningkatkan infrastruktur dan pelayanan publik (Asra \& Setiawina, 2012). Tercapainya pertumbuhan ekonomi mengindikasikan bahwa daerah tersebut berhasil menuntaskan kemiskinan, menaikan pendapatan masyarakat, serta naiknya standar hidup masyarakat (Lucky, 2013). Teoritis di atas menunjukkan bahwa pertumbuhan ekonomi menjadi suatu elemen yang penting untuk diketahui.

Untuk mengetahui tingkat pertumbuhan ekonomi pada suatu daerah, biasanya dilihat dengan angka Produk Domestik Regional Bruto atau PDRB (Wertianti \& Dwirandra, 2013; Zahari, 2017). Todaro \& Smith (2006) berpendapat bahwa PDRB adalah nilai total atas segenap output akhir yang dihasilkan oleh suatu perekonomian di tingkat daerah (baik itu yang dilakukan oleh penduduk daerah maupun penduduk dari daerah lain yang bermukim di daerah tersebut). Nominal PDRB menjadi penting untuk diketahui dikarenakan dapat dijadikan bahan analisis perencanaan dan patokan dalam mengukur hasil pembangunan yang dilaksanakan (Rahman \& Chamelia, 2015). Dengan kata lain, suatu daerah perlu mempertimbangkan tingkat pertumbuhan ekonomi yang diukur dengan PDRB demi pengambilan keputusan.

Salah satu daerah di Indonesia yang memiliki pertumbuhan ekonomi di bawah pertumbuhan ekonomi nasional adalah Aceh. Pertumbuhan ekonomi Aceh pada Triwulan 3 tahun 2019 hanya sebesar 3,76\%, berada di bawah perekonomian nasional yang telah berhasil mencapai $5,02 \%$. Hal tersebut terjadi dikarenakan Aceh belum begitu berkembang dan masih sangat bergantung pada realisasi APBA maupun APBK (BPS, 2019). Rendahnya pertumbuhan ekonomi juga diikuti dengan tingkat kemiskinan di Aceh, dimana BPS juga merilis bahwa Aceh menjadi daerah termiskin di Pulau Sumatera (urutan ke 6 Nasional) di tahun 2019, dan hal tersebut terjadi 3 kali berturut-turut.

Selanjutnya, beberapa studi sebelumnya juga telah membuktikan bahwa tingkat flypaper effect di Aceh begitu tinggi sehingga menghambat pertumbuhan ekonomi Aceh (Suyanto, 2015; Haryani, 2017; Zulfan \& Mustika, 2018). Dalam studi Azwar et al. (2013) juga menemukan bahwa 
pertumbuhan ekonomi di Aceh masih belum begitu merata, dimana masih terdapat beberapa daerah yang sangat tertinggal sehingga terjadi kesenjangan perekonomian dengan daerah lainnya.

Beberapa studi sebelumnya telah membuktikan bahwa pertumbuhan ekonomi daerah dipengaruhi oleh rasio-rasio kinerja keuangan daerah. Studi sebelumnya mendokumentasikan bahwa beberapa rasio keuangan daerah yang mempengaruhi pertumbuhan ekonomi adalah rasio kemandirian, efektivitas, efisiensi dan pertumbuhan PAD (Berliani, 2016; Kauda, 2016; Bongini et al., 2017; Harahap et al., 2018; Sati et al., 2019). Akan tetapi, masih terdapat beberapa studi yang menemukan bahwa rasio-rasio tersebut tidak berpengaruh signifikan terhadap pertumbuhan ekonomi (Fayissa \& Gutema, 2010; Ani \& Dwirandra, 2014; Guru \& Astuti, 2015; Yudav, 2019). Di sisi lain, studi yang dilakukan oleh Nurhayati (2015) merekomendasikan untuk menambahkan variabel yang belum dikajinya, yaitu rasio kemandirian dan rasio efektivitas untuk mengetahui faktor-faktor yang mempengaruhi pertumbuhan ekonomi. Penelitian Kusumawati \& Wiksuana (2018) juga merekomendasikan untuk menambahkan variabel efisiensi dan pertumbuhan $\mathrm{PAD}$ yang merupakan aspek keterbatasan dari penelitiannya.

\section{LITERATUR REVIEW DAN HIPOTESTS}

\section{Pengaruh Rasio Kemandirian terhadap Pertumbuhan Ekonomi}

Kemandirian daerah dapat dilihat dari seberapa besar daerah tersebut lebih tergantung pada dana pendapatan asli daerah dibandingkan dengan dana dari pusat (Swandewi, 2014). Nurhayati (2016) menambahkan bahwa kemandirian daerah merupakan indikator dari keberhasilan daerah dalam mengelola pendapatannya dalam APBD. Besarnya tingkat kemandirian suatu daerah dilihat dari besarnya perbandingan realisasi PAD terhadap total pendapatan daerah (Syamsudin et al., 2015).

Selanjutnya, tingkat kemandirian suatu daerah menggambarkan tingkat partisipasi masyarakat dalam membangun daerahnya. Tingginya kesadaran masyarakat dalam membangun daerahnya, seperti membayar pajak dan retribusi akan membuat daerah tersebut semakin berkembang dan kesejahteraan semakin meningkat, sehingga memberikan dampak positif terhadap pertumbuhan ekonomi daerah.

Sesuai dengan teori keagenan yang merupakan sebuah perjanjian antara satu atau lebih (prinsipal) menyewa orang lain (agen) dalam melakukan beberapa jasa untuk kepentingan prinsipal dengan memberikan beberapa wewenang kepada agen (Jensen \& Meckling, 1976). Pinsipal dalam hal ini adalah rakyat yang diwakili oleh DPRD memberikan wewenang kepada pemerintah daerah (agent) dalam meningkatkan pendapatan asli daerahnya melalui pembayaran pajak, retribusi dan sebagainya dan dari pelimpahan wewenang tersebut pemerintah daerah mampu memberikan pelayanan publik yang memadai yang didanai dari pendapatan daerah. Kontribusi yang diberikan oleh perwalikan rakyat kepada pihak pengelola pemerintah daerah menjadikan konstribusi mayor dalam meningkatkan PAD dan mendorong perekonomian daerah (Bongini, 2017). Uraian tersebut menunjukkan bahwa semakin mandiri suatu daerah, maka tingkat perekonomian daerah tersebut meningkat, sehingga rasio kemandirian daerah berpengaruh positif terhadap pertumbuhan ekonomi daerah (Berliani, 2016; Kauda, 2016; Harahap et al., 2018).

\section{Pengaruh Rasio Efektivitas terhadap Pertumbuhan Ekonomi}

Rasio efektivitas menunjukkan kemampuan pemerintah daerah dalam memobilisasi penerimaan PAD sesuai dengan yang ditargetkan (Mahmudi, 2010). Efektivitas daerah berkaitan dengan besarnya biaya yang digunakan daerah dalam mencapai pembangunan daerah (Ramadani, 2017). Efektivitas daerah juga melihat keberhasilan dari program-program daerah yang telah direncanakan oleh pemerintah daerah (Mardiasmo, 2004). Semakin efektivitas suatu daerah, maka program yang direalisasikan oleh daerah tersebut akan memberikan manfaat terhadap perekonomian rakyat (Harahap et al., 2018). Ini menunjukkan bahwa rasio efektivitas daerah memberikan efek positif terhadap pertumbuhan ekonomi daerah.

Rasio efektivitas berkaitan dengan tingkat realisasi dengan target PAD suatu daerah dalam satu periode (Sari et al., 2019). Sebagaimana riset sebelumnya juga mengimplikasikan bahwa daerah dengan PAD yang tinggi akan memiliki tingkat pertumbuhan ekonomi yang meningkat (Kusumawati \& Wiksuana, 2018). Efektivtas daerah juga berkaitan dengan tingkat investasi daerah, dimana daerah dengan efektivitas yang tinggi akan memberikan kontribusi optimal terhadap optimalisasi investasi daerah, sehingga mendorong peningkatan kinerja ekonomi daerah (Merton, 1992). Tingkat efektivitas daerah juga menjadi indikator kinerja keuangan daerah yang dapat meningkatkan tingkat investasi daerah yang telah direncanakan, sehingga meningkatkan kesejahteraan rakyat (Suryatini et al., 2018). Uraian tersebut juga telah dibuktikan oleh beberapa riset sebelumnya yang menemukan bahwa rasio 
efektivitas daerah berpengaruh positif terhadap pertumbuhan ekonomi (Fayissa \& Gutema, 2010; Berliani, 2016; Kauda, 2016; Bongini et al., 2017; Sari et al., 2019).

\section{Pengaruh Rasio Efisiensi terhadap Pertumbuhan Ekonomi}

Rasio efisiensi daerah merupakan rasio yang merefleksikan biaya yang dikeluarkan untuk memperoleh pendapatan (Ani \& Dwirandra, 2014). Mardiasmo (2004) mengatakan bahwa efesiensi diukur dengan rasio antara output dengan input. Semakin besar output dibanding input, maka semakin tinggi tingkat efisiensi suatu organisasi. Rasio efisiensi merefleksikan perbandingkan realisasi pengeluaran (belanja) dengan realisasi penerimaan daerah (Halim, 2008). Analisis tingkat efisiensi keuangan daerah dapat dihitung dengan menggunakan rasio efisienasi, yaitu rasio yang menggambarkan perbandingan antara output dan input atau realisasi pengeluaran dengan realisasi penerimaan daerah (Astuti, 2015).

Rasio efisiensi memberikan pengaruh terhadap pertumbuhan ekonomi daerah (Sari et al., 2019). Suatu kegiatan dikerjakan secara efisien jika pelaksanaan pekerjaan tersebut telah mencapai hasil (output) dengan biaya (input) yang terendah, atau dengan biaya minimal diperoleh hasil yang diinginkan (Dwiyandari et al., 2018). Rasio efisiensi adalah rasio yang menggambarkan perbandingan antara besarnya biaya yang dikeluarkan untuk memperoleh pendapatan dengan realisasi pendapatan yang diterima. Dengan mengetahui hasil perbandingan antara realisasi pengeluaran dan realisasi penerimaan, maka penilaian kinerja keuangan dapat ditentukan (Budiarto, 2007). Semakin kecil angka yang diperoleh, maka semakin efisien daerah tersebut (Halim, 2008). Daerah yang efisien akan memiliki pengeluaran yang lebih efektif, sehingga berimbas pada kesejahteraan rakyat. Rasio efisiensi juga menjadi indikator dalam melihat tingkat kesejahteraan rakyat daerah. Beberapa studi sebelumnya juga telah membuktikan bahwa efisiensi daerah memberikan pengaruh positif terhadap pertumbuhan ekonomi daerah (Fayissa \& Gutema, 2010; Berliani, 2016; Bongini et al., 2017; Harahap et al., 2018).

\section{Pengaruh Rasio Pertumbuhan Pendapatan terhadap Pertumbuhan Ekonomi}

Rasio pertumbuhan mengukur seberapa besar kemampuan suatu daerah dalam mempertahankan dan meningkatkan kesuksesan yang telah diraih dalam satu periode yang dilihat dari nilai PAD daerah tersebut (Ani \& Dwirandra, 2014). Semakin tinggi persentasi pertumbuhan setiap komponen pendapatan dan pengeluaran, maka semakin besar kemampuan daerah dalam mempertahankan dan meningkatkan keberhasilan yang dicapai dari setiap periodenya (Halim, 2008). Dengan diketahuinya rasio pertumbuhan untuk masingmasing komponen sumber pendapatan dan pengeluaran, dapat digunakan untuk mengevaluasi potensi-potensi mana yang perlu mendapat perhatian (Fayissa \& Gutama, 2010).

Rasio pertumbuhan pendapatan memberikan dampak positif terhadap pertumbuhan ekonomi (Saputra, 2017). Beberapa riset sebelumnya menggunakan pertumbuhan PAD sebagai proksi rasio pertumbuhan pendapatan (Ramadhani, 2017; Dewi \& Hafni, 2017). Peningkatan PAD di suatu daerah akan membuat daerah lebih mudah mengelola keuangan dan mengembangkan potensi-potensi daerah, sehingga tercipta multiplier effect kepada masyarakat dan meningkatkan perekonomian masyarakat sekitar (Setiyawati, 2018). Beberapa studi sebelumnya juga telah membuktikan bahwa rasio pertumbuhan perndapatan daerah berpengaruh positif terhadap pertumbuhan ekonomi (Berliani, 2016; Harahap et al., 2018; Mohieldin et al., 2019).

Berdasarkan uraian di atas, maka hipotesis yang dapat dibangun dalam penelitian ini disajikan pada tabel di bawah ini:

$\mathrm{H}_{1}$ : Rasio kemandirian daerah berpengaruh positif dan signifikan terhadap pertumbuhan ekonomi Kabupaten/Kota di Provinsi Aceh

$\mathrm{H}_{2}$ : Rasio efektivitas daerah berpengaruh positif dan signifikan terhadap pertumbuhan ekonomi Kabupaten/Kota di Provinsi Aceh

$\mathrm{H}_{3} \quad$ : Rasio efisiensi daerah berpengaruh positif dan signifikan terhadap pertumbuhan ekonomi Kabupaten/Kota di Provinsi Aceh

$\mathrm{H}_{4}$ : Rasio pertumbuhan pendapatan berpengaruh positif dan signifikan terhadap pertumbuhan ekonomi Kabupaten/Kota di Provinsi Aceh 


\section{METODE}

Penelitian ini dilakukan pada seluruh Kabupaten/Kota di Provinsi Aceh selama periode 2013-2018 yaitu sebanyak 23 Kabupaten/Kota. Data diperoleh dengan mengakses situs resmi Direktorat Jendral Perimbangan Keuangan (DJPK) yang diakses memalui situs resemi yaitu www.djpk.kemenkeu.go.id.

Jenis data yang digunakan dalam penelitian ini adalah data panel. Sugiyono (2016) mengatakan bahwa data Panel (pooled data) adalah data gabungan antara time series data dengan cross section data. Periode dalam penelitian ini selama selama 2013-2018 (time series) dan objek sebanyak 23 Kabupaten/Kota (Cross Section) sehingga banyaknya observasi dalam penelitian ini adalah 138 observasi.

Penelitian ini secara umum menggunakan 1 variabel terikat dan 4 variabel bebas. Variabel terikat dalam penelitian ini adalah pertumbuhan ekonomi yang diproksikan dengan nilai PDRB Kabupaten/Kota di Provinsi Aceh (Wertianti \& Dwirandra, 2013; Zahari, 2017). Sementara itu, variabel bebas dalam penelitian ini terdiri dari:

1. Rasio Kemandirian Daerah

Rasio kemandirian daerah dapat diukur dengan total PAD dibagi dengan total pendapatan (Syamsudin et al., 2015; Berliani, 2016; Harahap et al., 2018).

2. Rasio Efektivitas Daerah

Rumus yang dapat digunakan untuk melihat efektivitas daerah adalah relaisasi PAD dibagi dengan target PAD (Syamsudin et al., 2015; Ani \& Dwirandra, 2014; Harahap et al., 2018)

3. Rasio Efisiensi Daerah

Rasio efisiensi dalam penelitian ini dihitung dengan membagi realisasi belanja daerah dengan realisasi pendapatan daerah (Astuti, 2015; Syamsudin et al., 2015; Ani \& Dwirandra, 2014).

4. Rasio Pertumbuhan Pendapatan Daerah

Dalam penelitian ini, rasio pertumbuhan pendapatan diproksikan dengan pertumbuhan PAD (Ramadhani, 2017; Dewi \& Hafni, 2017; Saputra, 2017):

Selanjutnya, Analisis data yang digunakan untuk memecahkan permasalahan dalam penelitian ini adalah analisis regresi berganda data panel dengan bantuan program Eviews 9. Data panel merupakan sekelompok data individual yang diteliti selama rentang waktu sehingga data panel memberikan informasi observasi setiap individu dalam sampel (Gujarati dan Porter, 2009).

Model dasar dalam penelitian ini adalah sebagai berikut:

$Y_{i t}=\beta_{0}+\beta_{1} X_{1 i t}+\beta_{2} X_{2 i t}+\beta_{3} X_{3 i t}+\beta_{4} X_{4 i t}+e_{i t}$

Maka hipotesis statistiknya yaitu:

$\mathrm{H}_{01}: \mathrm{C}(2)=0$ vs $\mathrm{H}_{\mathrm{a} 1} \neq 0$

$\mathrm{H}_{02}: \mathrm{C}(3)=0$ vs $\mathrm{H}_{\mathrm{a} 2} \neq 0$

$\mathrm{H}_{03}: \mathrm{C}(4)=0$ vs $\mathrm{H}_{\mathrm{a} 3} \neq 0$

$\mathrm{H}_{04}: \mathrm{C}(5)=0$ vs $\mathrm{H}_{\mathrm{a} 4} \neq 0$

Dimana :

$\mathrm{Y}=$ Pertumbuhan ekonomi (PDRB)

$\mathrm{X} 1=$ Rasio Kemandirian Daerah

$\mathrm{X} 2=$ Rasio Efektivitas Daerah

$\mathrm{X} 3=$ Rasio Efisiensi Daerah

$\mathrm{X} 4=$ Rasio Pertumbuhan Pendapatan

$\mathrm{e}=$ errorterm

HASIL PENELITIAN DAN PEMBAHASAN Analisis Deskriptif Statistik 
Pada analisis statistik deskriptif, akan terlihat bagaimana nilai rata-rata, nilai standar deviasi, nilai maksimum dan nilai minimum dari data yang digunakan dalam penelitian ini. Adapun hasil analisis deskriptif dalam penelitian ini adalah sebagai berikut:

\section{Tabel 1}

Analisis Deskriptif Statistik

\begin{tabular}{lrrrrr}
\hline & \multicolumn{1}{c}{ Mean } & \multicolumn{1}{c}{ SD } & \multicolumn{1}{c}{ Max } & \multicolumn{1}{c}{ Min } & Obs \\
\hline LNPDRB & 28.9683 & 0.8122 & 30.3991 & 25.8306 & 138 \\
Kemandirian & 0.0838 & 0.0440 & 0.2576 & 0.0219 & 138 \\
Efektifitas & 0.9285 & 0.2947 & 1.3743 & 0.1672 & 138 \\
Efisiensi & 1.0046 & 0.0691 & 1.1949 & 0.7190 & 138 \\
Pertumbuhan & 0.3710 & 0.3348 & 1.1242 & -0.0373 & 138 \\
\hline
\end{tabular}

Sumber : Data Diolah, 2020

Berdasarkan Tabel 1, terlihat bahwa nilai rata-rata untuk PDRB (dalam satuan Logaritma Natural) dalam penelitian ini sebesar 28.9683 dengan standar deviasi sebesar 0.8122. Nilai rata-rata tersebut lebih tinggi dibandingkan dengan nilai standar deviasinya, yang menunjukkan bahwa fluktuasi PDRB dalam penelitian ini tergolong pada fluktuasi yang kecil. Nilai tertinggi PDRB sebesar 30.3991 dan nilai terendahnya sebesar 25.8306 dengan jumlah observasi sebanyak 138 pengamatan.

Selanjutnya, rasio kemandirian daerah memiliki nilai rata-rata sebesar $0.0838(8.38 \%)$ dengan nilai standar deviasinya sebesar 0.0440 (4.4\%). Nilai tersebut menunjukkan bahwa nilai ratarata berada di atas nilai standar deviasi, yang artinya rasio kemandirian daerah memiliki fluktuasi yang tergolong kecil. Nilai tertinggi rasio kemandirian daerah sebesar 0.2576 (25.76\%) dan nilai terendahnya sebesar 0.0219 (2.19\%) untuk 138 observasi.

Rasio efektifitas daerah memiliki nilai rata-rata sebesar 0.9285 (29.85\%) dengan nilai standar deviasinya sebesar 0.2947 (29.47\%). Nilai tersebut menunjukkan bahwa nilai rata-rata berada di atas nilai standar deviasi, yang artinya rasio efektifitas daerah memiliki fluktuasi yang tergolong kecil. Nilai tertinggi rasio efektifitas daerah sebesar $1.3743(137.43 \%)$ dan nilai terendahnya sebesar 0.1672 (16.72\%) untuk 138 observasi.

Selanjutnya, rasio efisiensi daerah memiliki nilai rata-rata sebesar $1.0046(100.46 \%)$ dengan nilai standar deviasinya sebesar $0.0691(6.91 \%)$. Nilai tersebut menunjukkan bahwa nilai rata-rata berada di atas nilai standar deviasi, yang artinya rasio efisiensi daerah memiliki fluktuasi yang tergolong kecil. Nilai tertinggi rasio efisiensi daerah sebesar 1.1949 (119.49\%) dan nilai terendahnya sebesar $0.0691(6,91 \%)$ untuk 138 observasi.

Selanjutnya, rasio pertumbuhan pendapatan memiliki nilai rata-rata sebesar $0.3710(37.1 \%)$ dengan nilai standar deviasinya sebesar 0.3348 (33.48\%). Nilai tersebut menunjukkan bahwa nilai ratarata berada di atas nilai standar deviasi, yang artinya rasio pertumbuhan pendapatan memiliki fluktuasi yang tergolong kecil. Nilai tertinggi rasio pertumbuhan pendapatan sebesar 1.1242 (112.42\%) dan nilai terendahnya sebesar $-0.0373(-3.73 \%)$ untuk 138 observasi

\section{Analisis Korelasi}

Analisis korelasi merupakan tahapan pengujian untuk melihat hubungan (korelasi) dari setiap variabel yang digunakan dalam penelitian ini. Adapun hasil analisis korelasi dalam penelitian ini dapat dilihat sebagai berikut:

Tabel 2

Analisis Korelasi

\begin{tabular}{|c|c|c|c|c|c|}
\hline & LNPDRB & Kemandirian Ef & fektifitas & Efisiensi & Pertumbuhan \\
\hline \multirow{2}{*}{ LNPDRB } & 1.0000 & & & & \\
\hline & ----- & & & & \\
\hline \multirow{2}{*}{ Kemandirian } & 0.3579 & 1.0000 & & & \\
\hline & $(4.4699) * * *$ & ----- & & & \\
\hline \multirow{2}{*}{ Efektifitas } & -0.1141 & 0.2934 & 1.0000 & & \\
\hline & $(-1.3404)$ & $(3.5803)^{* * * *}$ & ----- & & \\
\hline \multirow{2}{*}{ Efisiensi } & 0.0070 & 0.1168 & -0.0953 & 1.0000 & \\
\hline & $(0.0826)$ & (1.3716) ( & $(-1.1168)$ & ----- & \\
\hline
\end{tabular}




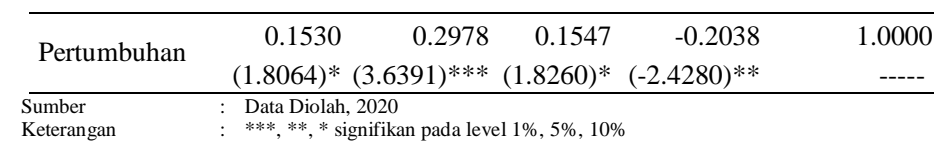

Berdasarkan Tabel 2, terlihat bahwa rasio kemandirian dan rasio pertumbuhan memiliki hubungan positif dengan pertumbuhan ekonomi (PDRB) dengan nilai korelasi masing-masing sebesar 0.3579 dan 0.1530 serta tergolong signifikan pada level $1 \%$ dan $10 \%$. Akan tetapi, rasio efisiensi memiliki hubungan positif tetapi tidak signifikan dengan pertumbuhan ekonomi (PDRB) dengan nilai korelasi sebesar 0.0070. Adapun efektifitas memiliki hubungan negatif tetapi tidak signifikan dengan pertumbuhan ekonomi (PDRB) dengan nilai korelasi -0.1141. Nilai korelasi pada hubugan efektifitas dengan pertumbuhan ekonomi (PDRB) yang negatif menunjukkan bahwa efektifitas daerah akan memberikan hubungan yang negatif pada pertumbuhan ekonomi jika di dalam model penelitian tidak terdapat rasio kinerja keuangan lainnya, dimana hal tersebut menunjukkan bahwa efektifitas malah menurunkan pertumbuhan ekonomi secara dikarenakan adanya realisasi anggaran daerah yang kurang tepat.

Selanjutnya, untuk hubungan antar variabel bebas, ditemukan bahwa rasio efektifitas dan pertumbuhan memiliki hubungan positif dengan rasio kemandirian dengan besaran korelasi 0.2934 dan 0.2978 serta tergolong signifikan di level $1 \%$, tetapi rasio efisiensi berkorelasi positif dengan kemandirian sebesar 0.1168 dan tergolong tidak signifikan. Adapun rasio pertumbuhan berkorelasi positif dengan rasio efektifitas sebesar 0.1547 dan signifikan di level $10 \%$, tetapi rasio efisiensi berkorelasi negatif dengan rasio kemandirian sebesar -0.0953 tetapi tidak signifikan. Rasio pertumbuhan berkorelasi negatif dengan rasio efisiensi sebesar -0.2038 dan signifikan di level $5 \%$.

\section{Teknik Pemilihan Model}

Agar model yang digunakan baik dan sesuai, maka diperlukan penaksiran model. Terdapat tiga model di dalam regresi data panel yaitu Common Effect Model (CEM) atau Pooled Least Square, Fixed Effect Model (FEM) dan Random Effect Model (REM). Untuk menentukan model terbaik dan yang sesuai dengan penelitian ini, maka uji yang dilakukan yaitu Uji Chow dan Uji Hausman. Uji Chow dilakukan untuk membandingkan model CEM dan FEM sedangkan Uji Hausman dilakukan untuk membandingkan FEM dan REM.

\section{Tabel 3}

Uji Chow

\begin{tabular}{lcc}
\hline \multicolumn{1}{c}{ Effects Test } & Statistic & Prob. \\
\hline Cross-section F & 59.1482 & 0.0000 \\
Cross-section Chi-square & 350.9915 & 0.0000 \\
\hline
\end{tabular}

Sumber : Data Diolah, 2020

Berdasarkan Tabel 3 di atas, ditemukan bahwa nilai probabilitas pada baris Chi Square sebesar 0.0000, dimana nilai tersebut di bawah nilai toleransi kesalahan dalam penelitian ini (0.05). Dengan kata lain, Uji Chow memilih FEM sebagai model yang tepat, sehingga dilanjutkan ke Uji Hausman.

Tabel 4

\section{Uji Hausman}

\begin{tabular}{lcc}
\hline \multicolumn{1}{c}{ Test Summary } & $\begin{array}{c}\text { Chi-Sq. } \\
\text { Statistic }\end{array}$ & Prob \\
\hline $\begin{array}{l}\text { Cross-section } \\
\text { random }\end{array}$ & 7.4058 & 0.1159 \\
\hline Sumber $\quad$ Data Diolah, 2020 &
\end{tabular}

Sumber : Data Diolah, 2020

Berdasarkan Tabel 4 di atas, ditemukan bahwa nilai proabilitas sebesar 0.1159, dimana nilai tersebut berada di atas nilai toleransi kesalahan dalam penelitian ini (0.05). Dengan kata lain, Uji 
Chow memilih REM sebagai model yang tepat, sehingga Uji Asumsi Klasik, Estimasi Regresi dan Pengujian Hipotesis dilakukan dengan Random Effect Model.

\section{Uji Asumsi Klasik \\ Uji Normalitas}

Uji normalitas digunakan untuk menguji model regresi mempunyai distribusi normal atau tidak. Uji normalitas yang dilakukan di dalam penelitian ini adalah Uji Jarque Bera. Pada Uji Jarque Bera, nilai yang dilihat adalah nilai probability. Suatu model regresi dikatakan memenuhi asumsi normalitas jika nilai probability lebih besar dari pada nilai standar toleransi kesalahan yaitu 0,05. Adapun hasil Uji normalitas disajikan pada Gambar 1 berikut:
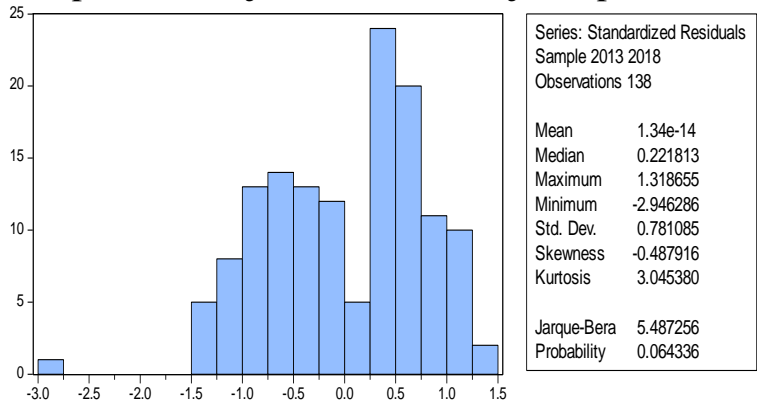

\section{Gambar 1 Uji Normalitas}

Berdasarkan Gambar 1, terlihat bahwa nilai probability sebesar 0.064336, dimana nilai tersebut berada di atas nilai toleransi kesalahan dalam penelitian ini (0.05). Maka dari itu, dapat disimpulkan bahwa data dalam penelitian ini telah terdistribusi secara normal.

\section{Uji Heteroskedastisitas}

Uji heteroskedastisitas merupakan salah satu uji asumsi klasik yang bertujuan untuk menguji apakah dalam model regresi terjadi ketidaksamaan varian residual antara yang satu dengan yang lain (Ghozali, 2011). Uji heteroskedastisitas yang digunakan di dalam penelitian ini adalah Uji Bruech Pagan Godfrey, dimana tahapannya yaitu membentuk nilai logaritma natural dari akar residual dan melakukan regresi pada seluruh variabel bebas terhadap nilai tersebut (Widarjono, 2017). Hasil Uji Bruech Pagan Godfrey dalam penelitian ini disajikan pada Tabel 5 berikut:

Tabel 5

\section{Uji Heteroskedastistas}

\begin{tabular}{cccc}
\hline Variable & Coefficient & t-Statistic & Prob. \\
\hline C & -0.2732 & -0.1575 & 0.8751 \\
KEMANDIRIAN & 3.6416 & 0.9980 & 0.3201 \\
EFEKTIFITAS & 0.0309 & 0.0715 & 0.9431 \\
EFISIENSI & -1.2780 & -0.7973 & 0.4267 \\
PERTUMBUHAN & -0.2222 & -0.5760 & 0.5656 \\
\hline
\end{tabular}

Sumber : Data Diolah, 2020

Berdasarkan Tabel 5, ditemukan bahwa nilai probability seluruh variabel bebas pada Uji Bruech Pagan Godfrey berada di atas nilai toleransi kesalahan dalam penelitian ini. Dengan kata lain, model penelitian yang digunakan terbebas dari masalah heteroskedastisitas.

\section{Uji Multikolinearitas}

Uji multikolinearitas adalah salah satu uji di dalam asumsi klasik bertujuan untuk melihat adanya atau tidaknya korelasi antar variabel independen di dalam penelitian. Ghozali (2011) mengatakan bahwa model yang baik adalah model dimana antar variabel bebas tidak memiliki kolerasi. Gujarati dan Porter (2012) menambahkan bahwa nilai korelasi antara nilai korelasi antara variabel bebas harus berada di bawah 0,8 .

Uji multikolinearitas di dalam penelitian ini dilakukan dengan melihat nilai korelasi antara variabel bebas Pada Tabel 2 Hasil Uji Korelasi. Terlihat bahwa seluruh cell antara variabel bebas di dalam penelitian ini memiliki nilai korelasi di bawah yang berada di bawah 0,8 . Maka dari itu, dapat 
disimpulkan bahwa tidak terjadi gejala multikolenearitas di dalam penelitian ini, artinya antara seluruh variabel bebas dalam penelitian ini tidak memiliki korelasi yang tinggi.

\section{Uji Autokorelasi}

Uji autokorelasi bertujuan untuk menguji dalam suatu model ada atau tidaknya korelasi antara kesalahan pengganggu pada periode $t$ dengan kesalahan pada periode $t-1$. Ghozali (2011) mengatakan bahwa model regresi yang baik adalah model yang tidak terdapat autokorelasi di dalamnya. Nilai Durbin Watson dalam penelitian ini sebesar 1.8975. Nilai tersebut berada di atas 1 dan bergerak mendekati angka 2. Dengan kata lain, model penelitian ini terbebas dari gejala autokorelasi.

\section{Estimasi Regresi Linear Berganda}

Hasil pemilihan model menunjukkan bahwa model yang tepat untuk diestimasikan dalam penelitian ini adalah Random Effect Model. Adapun hasil regresi secara Random Effect Model (REM) dapat dilihat pada Tabel 6 di bawah ini:

\section{Tabel 6}

Estimasi Regresi dengan Random Effect Model

\begin{tabular}{lcr}
\hline \multicolumn{1}{c}{ Variabel } & Koefisien & \multicolumn{1}{c}{ t-statistik } \\
\hline C & 28.3363 & $76.9626^{* * *}$ \\
KEMANDIRIAN & 1.5735 & $2.0959^{* *}$ \\
EFEKTIFITAS & 0.2302 & $2.6522^{* * *}$ \\
EFISIENSI & 0.6781 & $2.1356^{* *}$ \\
PERTUMBUHAN & 0.0876 & 1.1320 \\
\hline R-squared & & 0.2325 \\
Adjusted R-squared & & 0.2055 \\
F-statistic & $3.7995^{* * *}$ \\
Durbin-Watson & 1.8975 \\
\hline Sumber : Data Diolah, 2020 & \\
Keterangan : $* * * * *, *$ signifikan pada level $1 \%, 5 \%, 10 \%$
\end{tabular}

Berdasarkan Tabel 6, maka persamaan regresi yang dapat dibentuk adalah sebagai berikut:

LNPDRB $=28.3363+1.5735$ KEMANDIRIAN +0.2302 EFEKTIFITAS +0.6781 EFISIENSI + 0.0876PERTUMBUHAN

Berdasarkan persamaan di atas, terlihat bahwa nilai konstanta dalam penelitian ini sebesar 28.3363. Ini menunjukkan bahwa jika kemandirian daerah, efektifitas daerah, efisiensi daerah dan pertumbuhan pendapatan tidak bernilai (bernilai 0), maka pertumbuhan ekonomi (PDRB) akan tetap konstan di angka 28.3363. Selanjutnya, rasio kemandirian daerah memiliki nilai koefisien sebesar 1.5735. Ini menunjukkan bahwa ketika rasio kemandirian naik 1\%, maka pertumbuhan ekonomi (PDRB) akan meningkat sebesar 1.5735. Nilai koefisien tersebut juga tergolong signifikan secara statistik di level 5\% ( rob < 0.05). Dengan kata lain, rasio kemandirian berpengaruh positif dan signifikan terhadap pertumbuhan ekonomi (PDRB), sehingga $\mathrm{H}_{1}$ diterima.

Selanjutnya, rasio efektifitas daerah memiliki nilai koefisien sebesar 0.2302. Nilai tersebut menunjukkan bahwa jika rasio efektifitas daerah naik 1\%, maka pertumbuhan ekonomi (PDRB) akan meningkat sebesar 0.2302. Nilai koefisien tersebut juga tergolong signifikan secara statistik di level $1 \%$ ( prob < 0.01). Dengan kata lain, rasio efektifitas berpengaruh positif dan signifikan terhadap pertumbuhan ekonomi (PDRB), sehingga $\mathrm{H}_{2}$ diterima. Rasio efisiensi memiliki nilai koefisien sebesar 0.6781. Ini menunjukkan bahwa ketika rasio efisiensi naik 1\%, maka pertumbuhan ekonomi (PDRB) akan meningkat menjadi 0.6781. Nilai koefisien tersebut juga tergolong signifikan di level 5\% (prob $<0.05)$. Dengan kata lain, rasio efisiensi berpengaruh positif dan signifikan terhadap pertumbuhan eknomi (PDRB), sehingga $\mathrm{H}_{3}$ diterima. Adapun rasio pertumbuhan pendapatan memiliki nilai koefisien sebesar 0.0876. Hal ini menunjukkan bahwa ketika nilai rasio pertumbuhan pendapatan naik $1 \%$, maka pertumbuhan ekonomi akan meningkat menjadi 0.0876. Selain itu, nilai tersebut tidak 
tergolong signifikan secara statistik. Dengan kata lain, rasio pertumbuhan pendapatn tidak berpengaruh signifikan terhadap pertumbuhan ekonomi (PDRB), maka $\mathrm{H}_{4}$ ditolak.

Selanjutnya, nilai koefisien determinasi (Adjusted $R$ Square) dalam penelitian ini sebesar $0.2055(20.55 \%)$. Nilai tersebut menunjukkan bahwa rasio-rasio kinerja keuangan yang terdiri dari rasio kemandirian, efektifitas, efisiensi dan pertumbuhan pendapatan mampu menjelaskan pertumbuhan ekonomi sebesar $20.55 \%$, sedangkan sisanya (79.45\%) dijelaskan oleh variabel-variabel lain yang tidak dianalisis dalam penelitian ini. Adapun nilai F-statistik dalam penelitian ini sebesar 3.7995 yang tergolong signifikan di level $1 \%$. Ini menunjukkan bahwa rasio kemandirian, efektifitas, efisiensi dan pertumbuhan pendapatan secara bersama-sama berpengaruh terhadap pertumbuhan ekonomi (PDRB), sehingga model yang diestimasikan sudah layah (fit model). Adapun rekapitulasi hasil pengujian hipotesis disajikan pada Tabel 7

Tabel 7

Rekapitulasi Pengujian Hipotesis

\begin{tabular}{clc}
\hline Hipotesis & \multicolumn{1}{c}{ Pernyataan } & Keterangan \\
\hline $\mathrm{H}_{1}$ & $\begin{array}{l}\text { Rasio kemandirian daerah berpengaruh signifikan terhadap pertumbuhan } \\
\text { ekonomi pada Kabupaten/Kota di Provinsi Aceh }\end{array}$ & Diterima \\
$\mathrm{H}_{2}$ & $\begin{array}{l}\text { Rasio efektivitas daerah berpengaruh signifikan terhadap pertumbuhan } \\
\text { ekonomi pada Kabupaten/Kota di Provinsi Aceh }\end{array}$ & Diterima \\
$\mathrm{H}_{3}$ & $\begin{array}{l}\text { Rasio efisiensi daerah berpengaruh signifikan terhadap pertumbuhan } \\
\text { ekonomi pada Kabupaten/Kota di Provinsi Aceh }\end{array}$ & Diterima \\
$\mathrm{H}_{4}$ & $\begin{array}{l}\text { Rasio pertumbuhan pendapatan daerah berpengaruh signifikan terhadap } \\
\text { pertumbuhan ekonomi pada Kabupaten/Kota di Provinsi Aceh }\end{array}$ & Ditolak \\
\hline Sumber & : Data Diolah, 2020
\end{tabular}

\section{Pembahasan \\ Pengaruh Rasio Kemandirian Daerah terhadap Pertumbuhan Ekonomi}

Berdasarkan hasil analisis data yang telah dilakukan, ditemukan bahwa rasio kemandirian daerah memberikan pengaruh positif dan signifikan terhadap pertumbuhan ekonomi pada Kabupaten/Kota di Provinsi Aceh. Ini membuktikan bahwa semakin mandiri suatu daerah, maka tingkat pertumbuhan ekonominya akan meningkat. Hasil ini juga memberikan bukti empiris bahwa rasio kemandirian daerah menjadi prediktor dalam meningkatkan pertumbuhan ekonomi di Provinsi Aceh.

Kemandirian daerah menjadi indikator keberhasilan daerah dalam mengelola keuangannya (Nurhayati, 2016). Daerah dapat dikatakan mandiri jika daerah tersebut mampu meningkatkan pendapatan asli daerahnya dan tidak bergantung pada dana-dana transfer dari pusat, seperti DAU dan DAK. Meningkatnya PAD membuat sektor-sektor UMKM yang ada di daerah menjadi tumbuh, sehingga kesejahteraan masyarakat meningkat dan pertumbuhan ekonomi menjadi lebih baik. Hal ini dapat diwujudkan dengan peranan pihak-pihak pemegang kepentingan di daerah, seperti kepala daerah ataupun perwakilan daerah (legislatif), dimana kebijakan-kebijakan dalam menggali potensi daerah akan membuat pendapatan asli daerah meningkat, sehingga pertumbuhan ekonomi ikut meningkat.

Pengaruh positif yang diberikan oleh kemandirian daerah pada pertumbuhan ekonomi juga dikarenakan besarnya realisasi PAD di suatu daerah yang membuat daerah menjadi semakin mandiri dan mendorong peningkatan kesejahteraan masyarakat. Hal ini sejalan dengan teori desentralisasi fiskal, dimana pemberian otonom daerah akan berimplikasi pada kemandirian daerah dan kesejahteraan masyarakat daerah (Mardiasmo, 2006). Selain itu, rasio kemandirian daerah diukur dengan persentasi PAD pada total pendapatan daerah. Ini menunjukkan bahwa peranan PAD dalam meningkatkan pendapatan daerah akan memberikan dampak pada masyarakat, sehingga PDRB meningkat.

Selanjutya, kemandirian daerah juga berdampak pada pelayanan publik, dimana semakin mandiri daerah tersebut akan membuat pelayanan kepada rakyat semakin baik, sehingga perekonomian masyarakat meningkat (Bogini, 2017). Hasil riset ini juga sejalan dengan riset-riset sebelumnya yang telah membuktikan bahwa rasio kemandirian menjadi elemen yang dapat meningkatkan pertumuhan ekonomi daerah (Berliani, 2016; Kauda, 2016; Harahap et al., 2018). 


\section{Pengaruh Rasio Efektifitas Daerah terhadap Pertumbuhan Ekonomi}

Berdasarkan hasil analisis data yang telah dilakukan, ditemukan bahwa rasio efektivitas daerah berpengaruh positif dan signifikan terhadap pertumbuhan ekonomi. Ini menunjukkan bahwa semakin efektif suatu daerah, maka pertumbuhan ekonominya akan semakin membaik. Selain itu, hasil penelitian ini juga membuktikan bahwa rasio efektifitas daerah sebagai prediktor dalam meningkatkan pertumbuhan ekonomi.

Rasio efektfitas sendiri merupakan kemampuan pemerintah daerah dalam memobilisasi penerimaan PAD sesuai dengan apa yang telah ditargetkan (Mahmudi, 2010). Semakin efektif suatu daerah maka daerah tersebut akan menggunakan biaya yang tepat dalam mencapai pembangunan daerah, sehingga kesejahteraan meningkat dan pertumbuhan ekonomi masyarakat juga ikut meningkat. Selain itu, semakin efektif suatu daerah akan melambangkan kegiatan investasi daerah yang optimal, sehingga fasilitas dan pelayanan publik semakin baik dan kesejahteraan masyarakat meningkat (Merton, 1992).

Pengaruh positif yang diberikan rasio efektifitas pada pertumbuhan ekonomi daerah dikarenakan tingkat realisasi PAD yang tinggi akan memberikan dampak pada perekonomian masyarakat daerah, sehingga mendorong terjadinya pertumbuhan PDRB. Ini dapat dilihat dari proksi rasio efektifitas yang merupakan perbandingan realisasi PAD dengan target PAD, dimana realisasi yang tinggi akan membuat daerah semakin efektif (Syamsudin et al., 2015). Hal ini sejalan dengan teori desentralisasi, dimana peningkatan PAD yang tinggi mendorong kesejahteraan masyarakat, artinya pertumbuhan ekonomi daerah meningkat (Mardiasmo, 2006).

Selanjutnya, daerah yang efektif secara keuangan menunjukkan bahwa program-program yang direncanakan/ditargetkan berhasil dilakukan dan bermanfaat untuk rakyat, sehingga kesejahteraan dan pertumbuhan ekonomi akan meningkat (Harahap et al., 2018). Hasil penelitian ini juga sejalan dengan beberapa studi sebelumnya yang menemukan bahwa rasio efektifitas daera berpengaruh positif dan signifikan terhadap pertumbuhan ekonomi (Fayissa \& Gutema, 2010; Berliani, 2016; Kauda, 2016; Bongini et al., 2017; Sari et al., 2019).

\section{Pengaruh Rasio Efisiensi Daerah terhadap Pertumbuhan Ekonomi}

Hasil penelitian ini membuktikan bahwa rasio efisiensi daerah berpengaruh positif dan signifikan terhadap pertumbuhan ekonomi daerah. Ini menunjukkan bahwa semakin efisien daerah tersebut dalam mengelola keuangannya akan berdampak baik terhadap pertumbuhan ekonomi daerah. Selain itu, hasil penelitian ini juga membuktikan bahwa rasio efisiensi daerah menjadi prediktor dalam meningkatkan pertumbuhan ekonomi.

Rasio efisiensi daerah merupakan suatu gambaran keuangan yang menjelaskan tentang biaya yang dikeluarkan demi memperoleh pendapatan (Ani \& Dwirindra, 2014). Dengan mengeluarkan biaya yang optimal dan mampu memperoleh pemasukan yang banyak, maka akan terjadi keberhasilan program-program yang telah direncanakan oleh daerah, sehingga berdampak pada kesejahteraan daerah dan pertumbuhan ekonomi meningkat.

Pengaruh positif yang diberikan oleh rasio efisiensi daerah terhadap pertumbuhan ekonomi dikarenakan realisasi belanja daerah yang efisien membuat daerah dapat menghemat dana dan tidak terjadi investasi secara berlebihan (Fayissa \& Gutema, 2010). Realisasi belanja daerah yang tinggi menjadikan daerah dapat menggunakan dana yang tersisa ke bidang yang lainnya dalam meningkatkan SDM (Harahap et al., 2018).

Selanjutnya, semakin efisien daerah tersebut akan memberikan gambaran bahwa daerah memperoleh keuntungan dari minimalisasi biaya, sehingga dapat digunakan untuk kesejahteraan rakyat. Halim (2008) juga berpendapat bahwa rasio efisiensi sebagai indikator dalam meningkatkan kesejahteraan masyarakat. Hasil penelitian ini juga sejalan dengan hasil riset-riset sebelumnya yang menemukan bahwa rasio efisiensi daerah menjadi faktor yang dapat meningkatkan pertumbuhan ekonomi daerah (Fayissa \& Gutema, 2010; Berliani, 2016; Bongini et al., 2017; Harahap et al., 2018).

\section{Pengaruh Rasio Pertumbuhan Pendapatan terhadap Pertumbuhan Ekonomi}

Hasil penelitian ini telah memberikan bukti secara statistik bahwa rasio pertumbuhan pendapatan tidak berpengaruh signifikan terhadap pertumbuhan ekonomi. Ini menunjukkan bahwa meningkatkan PAD di suatu daerah tidak akan mendorong pertumbuhan ekonomi juga meningkat. 
Selain itu, hasil penelitianini juga membuktikan bahwa rasio pertumbuhan pendapatan bukanlah prediktor dalam meningkatkan pertumbuhan ekonomi.

Pengaruh yang tidak signifikan antara pertumbuhan pendapatan dengan pertumbuhan ekonomi dikarenakan masih belum optimalnya tingkat PAD yang ada di Kabupaten/Kota di Aceh. Ini menunjukkan bahwa PAD masih belum begitu tinggi di Aceh dan daerah-daerah di Aceh masih sangat bergantung pada dana transfer pusat. Selain itu, pengaruh tidak signifikan juga dikarenakan terjadi tingkat flypaper effect di Aceh, dimana flypaper effect merupaka suatu fenomena yang mendeskripsikan transfer pusat lebih tinggi dalam merespon belanja daerah dibandingkan PAD (Zulfan \& Mustika, 2018).

Selanjutnya, Ani \& Dwirandra (2014) berpendapat bahwa rasio pertumbuhan pendapatan berkaitan dengan kemampuan daerah dalam meningkatkan PAD. Hasil yang tidak signifikan dalam penelitian ini terjadi dikarenakan PAD yang tidak begitu tumbuh dan belum digalinya sumber-sumber PAD yang potensial di Aceh, sehingga tidak memberikan dampak signifikan terhadap pertumbuhan ekonomi. Aceh yang hanya bergantung ada pajak dan retribusi daerah dalam menaikkan PAD belum begitu mampu mendorong kesejahteraan masyarakat Aceh. Selain itu, ketergantungan Aceh pada dana tranfer pusat yang begitu besar (seperti OTSUS) menjadikan pihak pemegang kepentingan menjadi nyaman dengan dana tersebut dan tidak menggali potensi-potensi daerah dalam meningkatkan PAD. Hasil yang serupa juga pernah ditemukan oleh peneliti-peneliti sebelumnya yang mendokumentasikan bahwa rasio pertumbuhan daerah tidak berpengaruh signifikan terhadap pertumbuhan ekonomi daerah (Fayissa \& Gutema, 2010; Ani \& Dwirandra, 2014; Guru \& Yadav, 2019).

\section{KESIMPULAN DAN SARAN Kesimpulan}

Berdasarkan hasil penelitain yang telah dilakukan, maka kesimpulan yang dapat diambil dari penelitian ini adalah sebagai berikut:

1. Rasio kemandirian daerah berpengaruh positif dan signifikan terhadap pertumbuhan ekonomi pada Kabupaten/Kota di Provinsi Aceh.

2. Rasio efektifitas daerah berpengaruh positif dan signifikan terhadap pertumbuhan ekonomi pada Kabupaten/Kota di Provinsi Aceh.

3. Rasio efisiensi daerah berpengaruh positif dan signifikan terhadap pertumbuhan ekonomi pada Kabupaten/Kota di Provinsi Aceh.

4. Rasio pertumbuhan pendapatan daerah tidak berpengaruh signifikan terhadap pertumbuhan ekonomi pada Kabupaten/Kota di Provinsi Aceh.

\section{Saran}

Berdasarkan hasil kesimpulan di atas, maka saran yang dapat penulis berikan adalah sebagai berikut:

1. Rasio kemandirian daerah berpengaruh positif dan signifikan terhadap pertumbuhan ekonomi daerah, sehingga disarankan kepada Pemerintah Daerah Kabupaten/Kota di Provinsi Aceh untuk lebih menggali potensi-potensi daerah agar menghasilkan PAD yang tinggi agar Aceh menjadi lebih mandiri.

2. Rasio efektifitas daerah berpengaruh positif dan signifikan terhadap pertumbuhan ekonomi daerah, sehingga disarankan kepada Pemerintah Daerah Kabupaten/Kota di Provinsi Aceh untuk menargetkan kegiatan-kegiatan yang memberikan dampak baik terhadap pertumbuhan ekonomi masyarakat, agar PAD yang direalisasikan menjadi lebih besar.

3. Rasio efisiensi daerah berpengaruh positif dan signifikan terhadap pertumbuhan ekonomi daerah, sehingga disarankan kepada Pemerintah Daerah Kabupaten/Kota di Provinsi Aceh untuk melakukan belanja-belanja daerah yang memberikan dampak langsung pada perekonomian masyarakat.

4. Rasio pertumbuhan pendapatan tidak berpengaruh signifikan terhadap pertumbuhan ekonomi daerah, sehingga disarankan kepada peneliti lainnya untuk mengkaji faktor-faktor lain yang mempengaruh pertumbuhan ekonomi dengan objek yang berbeda dan periode waktu yang lebih panjang. 


\section{DAFTAR REFERENSI}

Ani, N. L. N. P., \& Dwirandra, A. A. N. B. (2014). Pengaruh Kinerja Keuangan Daerah pada Pertumbuhan Ekonomi, Pengangguran, dan Kemiskinan Kabupaten dan Kota. EJurnal Akuntansi, 481-497.

Arsa, I. K., \& Setiawina, N. D. (2016). Pengaruh Kinerja Keuangan pada Alokasi Belanja Modal dan Pertumbuhan Ekonomi Pemerintah Kabupaten/Kota se-Provinsi Bali Tahun 2006 sd 2013. Buletin Studi Ekonomi.

Arsyad, Lincoln. (2010). Ekonomi Pembangunan. Yogyakarta: Unit Penerbit dan Percetakan STIM YKPN Yogyakarta.

Astuti, W. (2015). Analisis pengaruh kinerja keuangan terhadap pertumbuhan ekonomi dan dampaknya terhadap pengangguran dan kemiskinan (studi pada Kabupaten dan Kota di Pulau Jawa periode 2007-2011). EBBANK, 6(1), 1-18.

Azwar, A., Hamzah, A., Masbar, R., \& Syahnur, S. (2013). Economic Growth Disparity Among the Regions in Aceh, Indonesia. Aceh International Journal of Social Sciences, 2(1).

Berliani, K. (2016). Pengaruh Kinerja Keuangan Terhadap Pertumbuhan Ekonomi dan Implikasinya Terhadap Kesejahteraan Masyarakat Kabupaten Majalengka. E-Jurnal STIE INABA, 15(2), 1-24.

Bongini, P., Iwanicz-Drozdowska, M., Smaga, P., \& Witkowski, B. (2017). Financial development and economic growth: the role of foreign-owned banks in CESEE countries. Sustainability, 9(3), 335.

Dewi, P. K., \& Hafni, N. (2017). Analisis rasio keuangan untuk mengukur kinerja keuangan pemerintah daerah Kabupaten Labuhan Batu tahun anggaran 2011-2013. KITABAH: Jurnal Akuntansi dan Keuangan Syariah, 1(1).

Dewi, Putu Ayu Krisna dan I Ketut Sutrisna. (2014). Pegaruh Kemandirian Keuangan Daerah dan Pertumbuhan Ekonomi Terhadap Indeks Pembangunan Manusia di Provinsi Bali. E-Jurnal Ekonomi Pembangunan Universitas Udayana Vol 4, No 1.

Dwiyandari, L. D. Y., \& Badera, I. D. N. (2018). Pengaruh Kinerja Keuangan pada Belanja Daerah dan Pertumbuhan Ekonomi dan Implikasinya Pada Indeks Pembangunan Manusia. E-Jurnal Akuntansi, 1741-1770.

Fayissa, B., \& Gutema, P. (2010). Dependency ratio and the economic growth puzzle in subSaharan Africa. Department of Economics and Finance Working Paper series.(Assessed on 22 December 2010 from http://ideas. repec. org/p/mts/wpaper/201010. html).

Ghozali, Imam. (2011). Aplikasi Analisis Multivariete dengan Program IBM SPSS 23. (Edisi ke 8). Badan Penerbit Universitas Diponegoro, Semarang.

Gujarati, Damodar N \& Dawn C Porter. (2012). Dasar-Dasar Ekonometrika. (Raden Carlos Mangungsong, Penerjemah.). (Edisi 5). Salemba Empat, Jakarta.

Guru, B. K., \& Yadav, I. S. (2019). Financial development and economic growth: panel evidence from BRICS. Journal of Economics, Finance and Administrative Science, 24(47), 113-126.

Gustiana, Andi. (2014). Pendapatan Asli Daerah, Dana Alokasi Umum dan Belanja Modal Terhadap Pertumbuhan Ekonomi (Studi Empiris pada Pemerintah Kabupaten Soppeng periode 2005-2012). Tesis Fakultas Ekonomi dan Bisnis Universitas Hasanuddin. Dipublikasikan.

Halim, A. (2008). Akuntansi Keuangan Daerah Edisi Revisi 3. Salemba Empat Jakarta.

Harahap, J. P. R., Daulay, M., \& Torong, Z. B. (2018). Pengaruh Faktor-Faktor Kinerja Keuangan, Size, Leverage, dan Pendapatan Asli Daerah Terhadap Pertumbuhan Ekonomi Dengan Alokasi Belanja Modal Sebagai Variabel Moderating Pada 
Kabupaten/Kota di Provinsi Sumatera Utara. KITABAH: Jurnal Akuntansi dan Keuangan Syariah.

Haryani, H. (2017). Analisis Flypaper Effect Pada Pemerintah Provinsi Aceh. Ekonis: Jurnal Ekonomi dan Bisnis, 18(2).

Haviz, Teuku. (2016). Pengaruh Pendapatan Asli Daerah, Dana Perimbangan, Belanja Modal dan Kemiskinan Terhadap Pertumbuhan Ekonomi di Provinsi Aceh. Tesis Program Pascasarjana Ilmu Manajemen, Fakultas Ekonomi dan Bisnis, Universitas Malikussaleh. Tidak Dipublikasikan.

Kuada, J. (2016). Financial market performance and growth in Africa. African Journal of Economic and Management Studies, 7(2).

Kusumawati, L., \& Wiksuana, I. G. B. (2018). Pengaruh Pendapatan Daerah terhadap Pertumbuhan Ekonomi di Wilayah Sarbagita Provinsi Bali. E-Jurnal Manajemen Universitas Udayana, 7(5).

Lucky, D. (2013). Analysis Of The Effect Of Regional Financial Performance To Economic Growth and Poverty Through Capital Expenditure (Case study of 38 Regencies/Cities in East Java Province). Journal of Economics and Sustainable Development, 4(19), 7-17.

Mamesah, D. J. (2017). Sistem Administrasi Keuangan Daerah. Gramedia Pustaka Utama, Jakarta.

Manggu, S. A. R. (2019). Analisis Kemampuan Keuangan Daerah Pemerintah Kabupaten Majene. Jurnal Akrab Juara, 4(1), 45-55.

Mardiasmo. (2004). Otonomi dan Manajemen Keuangan Daerah. Andi, Yogyakarta.

Merton, R. C. (1992). Financial innovation and economic performance. Journal of applied corporate finance, 4(4), 12-22.

Mohieldin, M., Hussein, K., \& Rostom, A. (2019). On financial development and economic growth in Egypt. Journal of Humanities and Applied Social Sciences.

Mundlak, Y. (2001). Explaining economic growth. American Journal of Agricultural Economics, 83(5), 1154-1167.

Nurhayati, Mafizatun. (2015). Pengaruh Kemandirian Daerah, Investasi Pemerintah, Angkatan Kerja dan Pendapatan Perkapita Terhadap Pertumbuhan Ekonomi Daerah di 33 Provinsi Tahun 2008 - 2013. Jurnal Ilmiah Manajemen dan Bisnis. Volume 1, Nomor 3.

Peterson, E. W. F. (2017). The role of population in economic growth. SAGE Open, 7(4), 2158244017736094.

Raharjo, A. (2013). Teori-Teori Pembangunan Ekonomi: pertumbuhan ekonomi dan pertumbuhan wilayah. Yogyakarta: Graha Ilmu.

Rahman, Y. A., \& Chamelia, A. L. (2015). Faktor-faktor yang mempengaruhi pdrb kabupaten/kota jawa tengah tahun 2008-2012. JEJAK: Jurnal Ekonomi dan Kebijakan, 8(1).

Ramadani, R. F. (2017). Analisis Kinerja Anggaran dan Realisasi Pendapatan dan Belanja Daerah Permerintah Kota Samarinda. Ekonomia, 5(3), 327-345.

Resosudarmo, B., Yusuf, A. A., Hartono, D., \& Nurdianto, D. (2011). Regional Economic Modelling for Indonesia: Implementation of IRSA-INDONESIA5.

Rukayah, R., Kusumawati, N., \& Afriani, R. I. (2017). Analisis Laporan Realisasi Anggaran Dengan Menggunakan Rasio Efektivitas Dan Rasio Efisiensi Pada Kantor Badan Perijinan Terpadu Dan Penanaman Modal Kabupaten Serang. JAK (Jurnal Akuntansi): Kajian Ilmiah Akuntansi, 4(2).

Rustiono, Deddy. (2008). Analisis Pengaruh Investasi, Tenaga Kerja, Dan Pengeluaran Pemerintah Terhadap Pertumbuhan Ekonomi Di Propinsi Jawa Tengah. Jurnal EMBA, 1(2). 
Sajow, C., Morasa, J., \& Wokas, H. R. (2017). Analisis Realisasi Anggaran Belanja Daerah Pada Pemerintah Kota Tomohon Dan Pemerintah Kabupaten Minahasa Selatan. Jurnal EMBA: Jurnal Riset Ekonomi, Manajemen, Bisnis dan Akuntansi, 5(2).

Saputra, R. W. (2017). Analisis Kinerja Keuangan Daerah Ditinjau dari Rasio Keuangan (Studi Kasus di Kabupaten Jepara Tahun Anggaran 2013-2015) (Doctoral dissertation, Universitas Muhammadiyah Surakarta).

Sari, G. N., Kindangen, P., \& Rotinsulu, T. O. (2019). Pengaruh Kinerja Keuangan Terhadap Pertumbuhan Ekonomi Perkotaan di Sulawesi Utara Tahun 2004-2014. Jurnal Pembangunan Ekonomi dan Keuangan Daerah, 18(2).

Setiyawati, H. (2018). The Effect Ofthe Locally-Generated Revenue and the General Allocation Fund on the Capital Expenditure (Survey on the Provincial/District/City Region Banten and DKI Jakarta). Profita, 9(3), 407-421.

Sugiyono. (2016). Metode Penelitian Bisnis (Pendekatan Kuantitatif, Kualitatif dan R\&D). Alfabeta, Bandung.

Sukirno, Sadono. (2013). Ekonomi Pembangunan. Penerbit FEUI, Jakarta.

Suyanto, S. (2015). Flypaper Effect Theory Dalam Implementasi Kebijakan Desentralisasi Fiskal. Jurnal Ekonomi Pembangunan: Kajian Masalah Ekonomi dan Pembangunan, 11(1), 69-92.

Swandewi, Anak Agung Istri Agung. (2014). Pengaruh Dana Perimbangan dan Kemandirian Keuangan Daerah Terhadap Keserasian Anggaran dan Kesejahteraan Masyarakat pada Kabupaten/Kota di Provinsi Bali. Jurnal Ekonomi dan Bisnis. Vol 3, No 7.

Syamsudin, S., Cahya, B. T., \& Dewi, S. N. (2015). Pengaruh Kinerja Keuangan terhadap Pertumbuhan Ekonomi, Pengangguran dan Kemiskinan. Jurnal Manajemen Dayasaing, 17(1), 15-27.

Todaro, M. P. dan S.C. Smith. (2006). Pembangunan Ekonomi. Jilid I. Edisi ke 9. Erlangga, Jakarta.

Wertianti, I. G., \& Dwirandra, A. A. N. B. (2013). Pengaruh Pertumbuhan Ekonomi Pada Belanja Modal Dengan PAD dan DAU Sebagai Variabel Moderasi. E-Jurnal Akuntansi, 567-584.

Yunitasari, Mariana. (2016). Peran Investasi Sumber Daya Manusia dan Foreign Direct Investment (FDI) Terhadap Pertumbuhan Ekonomi di Enam Negara Asean. Jurnal Akuntansi dan Keuangan Daerah, 1(2).

Zahari, M. (2017). Pengaruh Pertumbuhan Ekonomi terhadap Pendapatan Asli Daerah di Provinsi Jambi. Jurnal Ilmiah Universitas Batanghari Jambi, 15(4), 170-181.

Zulfan, T., \& Mustika, E. (2018). Pengaruh Dana Otonomi Khusus terhadap Fly paper effect di Provinsi Aceh. Jurnal EMT KITA, 2(1), 19-27. 